\title{
PENGAMATAN LOGAM BERAT PADA SEDIMEN PERAIRAN WADUK CIRATA
}

\author{
Adang Saputra \\ Pusat Riset Perikanan Budidaya \\ Jl. Ragunan 20, Pasar Minggu, Jakarta Selatan 12540 \\ E-mail: adang@ cria.indosat.net.id
}

\begin{abstract}
ABSTRAK
Waduk Cirata merupakan waduk serbaguna yang terletak di tiga kabupaten yaitu: Purwakarta, Cianjur, dan Bandung Provinsi Jawa Barat, telah mengalami penurunan daya guna akibat pengaruh lingkungan yang terlalu berat. Penurunan daya guna tersebut bisa bersifat fisik, kimia, maupun biologi. Salah satu kontaminan yang masuk ke Waduk Cirata adalah terakumulasinya logam berat di dasar perairan (sedimen). Untuk mengukur konsentrasi logam berat pada sedimen, dilakukan dengan pengambilan contoh sedimen pada bagian hulu, tengah, dan hilir Waduk Cirata. Hasil analisis menunjukkan bahwa konsentrasi logam berat tertinggi yaitu: $\mathrm{F}$ (besi) konsentrasinya sebesar 29,495 mg/kg, Hg (merkuri) konsentrasinya pada sedimen sebesar $26,83 \mathrm{mg} / \mathrm{kg}$, kemudian disusul oleh logam berat Pb (timbal) sebesar $2,38 \mathrm{mg} / \mathrm{kg}$; dan terakhir logam $\mathrm{Cd}$ (kadmium) sebesar 0,29 $\mathrm{mg} / \mathrm{kg}$. Tingginya konsentrasi logam berat pada sedimen tersebut dapat berpotensi meningkatkan akumulasi logam berat pada ikan yang dipelihara baik melalui rantai makanan maupun osmeroegulasi. Dari hasil analisis terhadap daging ikan patin ternyata peningkatan akumulasi logam berat terjadi pada akhir pemeliharaan jika dibandingkan dengan awal pemeliharaan. Dampak lain dari tingginya akumulasi logam berat bisa merusak jaringan organ tubuh ikan dan pada akhirnya mengakibatkan kematian ikan.
\end{abstract}

\section{KATAKUNCl: Waduk Cirata, akumulasi logam berat, sedimen}

\section{PENDAHULUAN}

Waduk Cirata merupakan waduk serbaguna yang terletak di tiga kabupaten yaitu: Purwakarta, Cianjur, dan Bandung Provinsi Jawa Barat, telah mengalami penurunan daya guna akibat pengaruh lingkungan yang ditimbulkan terlalu berat. Penurunan daya guna ini dapat berupa penurunan kualitas perairan yang bersifat fisik, kimia, maupun biologi. Salah satu kontaminan yang masuk ke Waduk Cirata adalah logam berat.

Menurut penelitian Amin (2008), jenis logam berat pada tubuh ikan mas yang dipelihara di Waduk Cirata, yaitu: $\mathrm{Hg}(0,00131 \mathrm{mg} / \mathrm{kg}) ; \mathrm{Pb}(0,61 \mathrm{mg} / \mathrm{kg}) ; \mathrm{Cd}(0,075$ $\mathrm{mg} / \mathrm{kg}) ; \mathrm{Zn}(40,09 \mathrm{mg} / \mathrm{kg}) ; \mathrm{Cu}(3,37 \mathrm{mg} / \mathrm{kg}) ;$ dan Ni $(2,26$ $\mathrm{mg} / \mathrm{kg}$ ). Menurut penelitian Saputra (2009), logam berat $\mathrm{Hg}, \mathrm{Pb}, \mathrm{Cd}$, dan Fe memberikan dampak yang cukup besar terhadap pencemaran pada ikan patin yang dibudidayakan maupun perairan Waduk Cirata itu sendiri.

Akumulasi logam berat besi (Fe) yang ada di Waduk Cirata salah satunya dihasilkan dari aktivitas kegiatan perikanan. Dimana pada tahun 2009 jumlah KJA yang ada di Waduk Cirata sebanyak 51.418 unit dengan jumlah rumah tangga petani (RTP) 2.838 (Anonim, 2009). Menurut Anonim (2009), material yang digunakan untuk pembuatan KJA adalah pelampung terbuat dari sekitar $56,06 \%$ besi (Fe) dan 43,94\% berupa styrofoam (bahan kimia) yang memberikan kontribusi terhadap pencemaran waduk. Sumber lain yang memberikan dampak tingginya konsentrasi logam berat Fe di Waduk Cirata adalah eksploitasi timbunan biji besi dalam membongkar permukaan batu bara dan sejumlah besar sisa-sisa batu atau tanah untuk mempercepat kondisi pelapukan dan cairan limbah rumah tangga (Wittman 1979 dalam Connel \& Miller, 2006).

Logam berat timbal $(\mathrm{Pb})$ di Waduk Cirata banyak dihasilkan dari lalu lintas kapal/ perahu, limbah buangan industri, limbah rumah tangga yang mengalir melalui aliran air sungai yang masuk ke dalam waduk. Menurut William et al. (2000) dalam Oktavianus \& Salmi (2005), mengemukakan bahwa timbal berasal dari industri-industri seperti pabrik baterai, amunisi, kawat, logam campuran, dan cat. Secara alamiah logam masuk ke dalam perairan melalui pengkristalan timbal di udara dengan bantuan air hujan dan proses korotifikasi batu-batuan mineral.

Kadmium (Cd) banyak dipakai pada industri metalurgi, pelapisan logam, pigmen baterai, peralatan elektronik, pelumas, peralatan fotografi, gelas keramik, tekstil, dan 
plastik (Eckenfelder, 1989). Sehingga konsentrasi logam $\mathrm{Pb}$ di Waduk Cirata cukup tinggi, karena kegiatan yang menjadi sumber logam berat $\mathrm{Pb}$ banyak membuang limbahnya ke Sungai Citarum di mana Sungai Citarum merupakan pemasok air utama bagi Waduk Cirata.

Merkuri adalah unsur renik pada kerak bumi, yakni hanya sekitar 0,08 mg/kh (Moore, 1991). Pada perairan alami, merkuri hanya ditemukan dalam jumlah yang sangat kecil. Merkuri merupakan satu-satunya logam yang berada dalam bentuk cairan pada suhu normal. Senyawa merkuri digunakan dalam pembuatan pencucian emas, cat, komponen listrik, baterai, ekstraksi emas dan perak, gigi palsu, senyawa anti karat, fotografi, dan elektronik (Eckenfelder, 1989). Akumulasi logam berat merkuri di Waduk Cirata cukup tinggi, karena di bagian hulu sungai Citarum ada penambangan emas yang banyak membuang limbah sisa pencuciannya ke Sungai Citarum yang menjadi pemasok air utama bagi Waduk Cirata.

Secara umum dampak logam berat khususnya akibat dari pencemaran, menyebabkan terjadi perubahan struktur komunitas perairan, jaring makanan, tingkah laku biota, efek fisiologi, genetika, dan resistensi terhadap penyakit (Moriarty, 1987).

Di dalam ekosistem perairan logam berat berikatan dalam senyawa kimia atau dalam bentuk logam ion, bergantung pada kompartemen tempat logam tersebut berada. Akumulasi logam berat di perairan Waduk Cirata tertinggi yaitu pada kompartemen sedimen. Sehingga kompartemen sedimen ini menjadi kompartemen dominan.

Dampak dari akumulasi logam berat ini, selain mencemari perairan, juga menurunkan tingkat kematangan gonad, menutup membran insang sehingga ikan kekurangan oksigen, menghambat pertumbuhan, dan ikan tidak aman untuk dikonsumsi.

\section{PENGAMBILAN SAMPEL}

Sampel sedimen yang dikumpulkan yaitu dari dasar perairan Waduk Cirata pada bagian hulu, tengah, dan hilir dengan menggunakan alat ekman grab. Contoh daging ikan patin untuk dianalisis logam beratnya baik pada awal pemeliharaan maupun pada akhir pemeliharaan (sekitar 6 bulan pemeliharaan) diambil dari keramba jaring apung (KJA). Sampel yang telah dikumpulkan, selanjutnya dianalisis di Laboratorium Balai Besar Pengembangan Budidaya Air Tawar, Sukabumi. Proses pengambilan contoh sedimen, contoh daging ikan patin, dan keramba jaring apung yang digunakan untuk pemeliharaan ikan patin disajikan pada Gambar 1, 2, 3.

Contoh sedimen yang diambil dari ketiga stasiun tadi, kemudian dicampurkan dengan bobot yang sama untuk selanjutnya dianalisis logam beratnya dengan menggunakan Atumic Absorbsion Spectrophotometer (AAS). Untuk contoh air yang diambil dari bagian permukaan pada setiap stasiun, kemudian dicampurkan dengan volume yang sama dari tiap-tiap stasiun dan selanjutnya dianalisis logam beratnya. Sedangkan contoh daging ikan patin baik pada awal maupun akhir pemeliharaan diambil dari tiga ekor, untuk selanjutnya dilakukan analisis logam beratnya.

\section{HASIL DAN BAHASAN}

Bioakumulasi menurut Semichal (2008), lebih banyak ke arah bagian yang terpisah (kompartemen) yaitu sedimen sedangkan biokonsentrasi lebih ke arah akumulasi pada hewannya. Bioakumulasi menurut Soemirat (2003) bisa dihitung dengan menggunakan rumus koefisien determinasi $(\mathrm{Kd})$ yaitu:

$$
\mathrm{Kd}=\frac{\{\text { logam berat }\} \text { lumpur }}{\{\text { logam berat }\} \text { air }}
$$

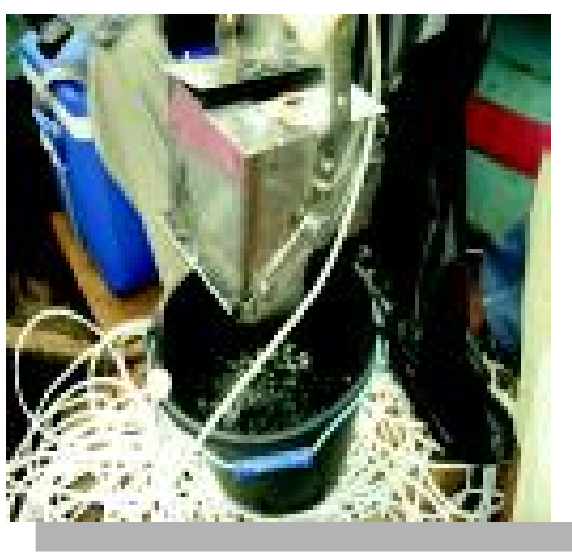

Gambar 1. Pengambilan sedimen

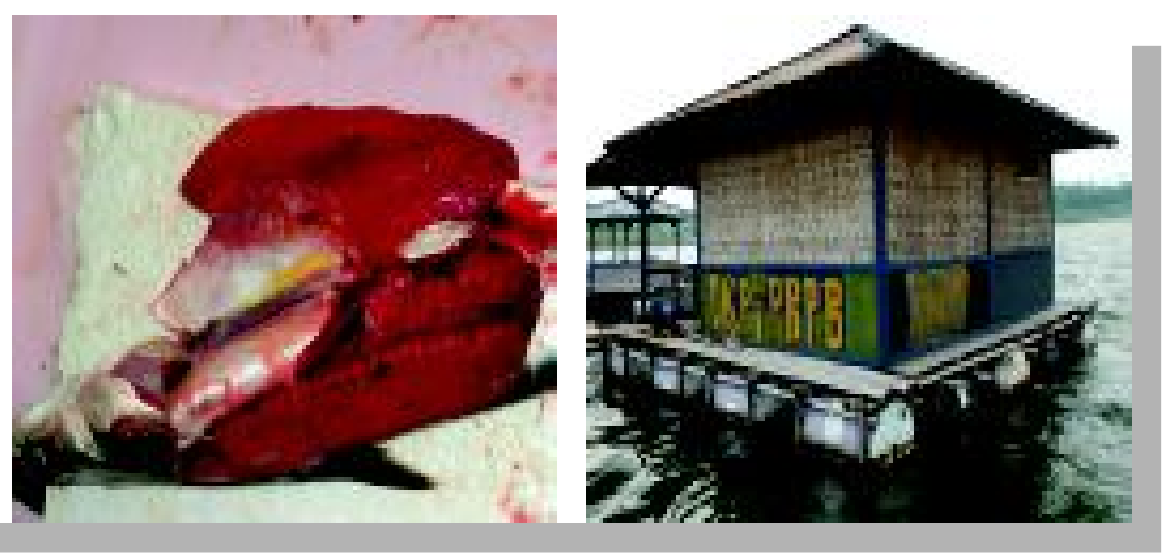

Gambar 2. Pengambilan daging ikan Gambar 3. KJA untuk pemeliharaan ikan patin 
Rangkuman hasil dari perhitungan dengan menggunakan humus Kd disajikan pada Tabel 1. Dari Tabel 1 terlihat bahwa jumlah konsentrasi logam berat yang diamati pada sedimen ada hubungan yang signifikan dengan konsentrasi yang ada di air. Status keterkaitannya sudah masuk dalam ketegori afinitas tinggi. Karena statusnya sudah afinitas tinggi, sehingga pada saat tertentu apabila logam berat yang terakumulasi pada sedimen tredegradasi, maka perairan menjadi sangat toksik dan bisa bisa mematikan binatang akuatik yang ada di perairan tersebut.

Tabel 1. Rangkuman hasil perhitungan koefisien determinasi $(K d)$ pada sedimen dan air Waduk Cirata

\begin{tabular}{lccc}
\hline Jenis logam berat & Nilai Kd & $\begin{array}{c}\text { Kategori } \\
\text { afinitas }\end{array}$ & Keterangan \\
\hline Timbal $(\mathrm{Pb})$ & 22,7 & $>5$ & Tinggi \\
Kadmium $(\mathrm{Cd})$ & 9,14 & $>5$ & Tinggi \\
M erkuri $(\mathrm{Hg})$ & $13.415,50$ & $>5$ & Tinggi \\
Besi $(\mathrm{Fe})$ & 166,33 & $>5$ & Tinggi \\
\hline
\end{tabular}

Dari hasil nilai uji korelasi terhadap sedimen dan air hasilnya menunjukkan ada hubungan yang erat antara peningkatan konsentrasi akumulasi logam berat pada sedimen, akan diikuti dengan penurunan konsentrasi logam berat pada air. Karena dalam perairan pada umumnya logam berat berikatan dalam bentuk senyawa kimia atau dalam bentuk logam ion, bergantung pada kompartemen logam tersebut berada. Tingkat kandungan logam berat pada setiap kompartemen sangat bervariasi, bergantung pada lokasi, jenis kompartemen, dan tingkat pencemaran. Menurut Hart \& Lake (1987), kompartemen sedimen di dasar perairan merupakan kompartemen terbesar dari logam berat pada setiap ekosistem air.

Hal ini disebabkan karena logam berat tidak bisa diuraikan di alam secara total dan sifatnya akumulasi. Hasil analisis logam berat pada sedimen dan air Waduk Cirata disajikan pada Tabel 2.

Pada Tabel 2 terlihat bahwa akumulasi logam berat Fe (besi) konsentrasinya paling tinggi yaitu sebesar 29,495 $\mathrm{mg} / \mathrm{kg}$. Logam berat $\mathrm{Hg}$ (merkuri) konsentrasinya pada sedimen sebesar $26,83 \mathrm{mg} / \mathrm{kg}$; kemudian disusul oleh logam berat Pb (timbal) sebesar 2,38 mg/kg; dan terakhir logam Cd (kadmium) sebesar 0,29 mg/kg.

Menurut Saputra (2009), sumber-sumber logam berat yang memberikan konstribusi terhadap peningkatan akumulasi pada perairan Waduk Cirata diantaranya kegiatan
Tabel 2. Hasil analisis logam berat pada sedimen dan air

\begin{tabular}{ccc}
\hline Kompartemen & $\begin{array}{c}\text { Jenis } \\
\text { logam berat }\end{array}$ & $\begin{array}{c}\text { Jumlah } \\
\text { (mg/kg bobot basah) }\end{array}$ \\
\hline \multirow{3}{*}{ Sedimen } & $\mathrm{Pb}$ & 2,383 \\
& $\mathrm{Cd}$ & 0,317 \\
& $\mathrm{Hg}$ & 26,831 \\
& $\mathrm{Fe}$ & 29,495 \\
Air & $\mathrm{Hg}$ & 0,291 \\
& $\mathrm{Cd}$ & 0,035 \\
& $\mathrm{~Pb}$ & $\mathrm{TTD}$ \\
& $\mathrm{Fe}$ & 0,122 \\
\hline
\end{tabular}

Keterangan: $\mathrm{Pb}$ (Timbal), Cd (Kadmium), $\mathrm{Hg}$ (Merkuri), Fe (Besi), TTD (Tidak terd eteksi)

pertambangan, kegiatan industri, transportasi, pertanian, dan limbah buangan domestik baik yang masuk melalui aliran sungai maupun dari limbah domestik rumah tangga petani yang melakukan kegiatan budidaya ikan dengan keramba jaring apung. Konsentrasi logam berat Fe dan $\mathrm{Hg}$ sudah sangat tinggi dan melebihi standar baku mutu untuk kegiatan budidaya ikan, sedangkan unuk logam berat $\mathrm{Pb}$ dan $\mathrm{Cd}$ walaupun sudah melebihi standar untuk budidaya ikan, tetapi masih dalam batas yang dapat ditoleransi.

Pada Gambar 4 terlihat bahwa semua logam berat yang dianalisis, akumulasinya pada sedimen lebih tinggi jika dibandingkan dengan akumulasinya pada air. Hal ini terjadi karena sifat dari logam berat yang ionik, sehingga mudah terikat oleh substrat pada dasar perairan. Walaupun demikian, logam berat ini bisa terakumulasi oleh ikan yang ada di Waduk Cirata melalui rantai makanan dan osmoregulasi.

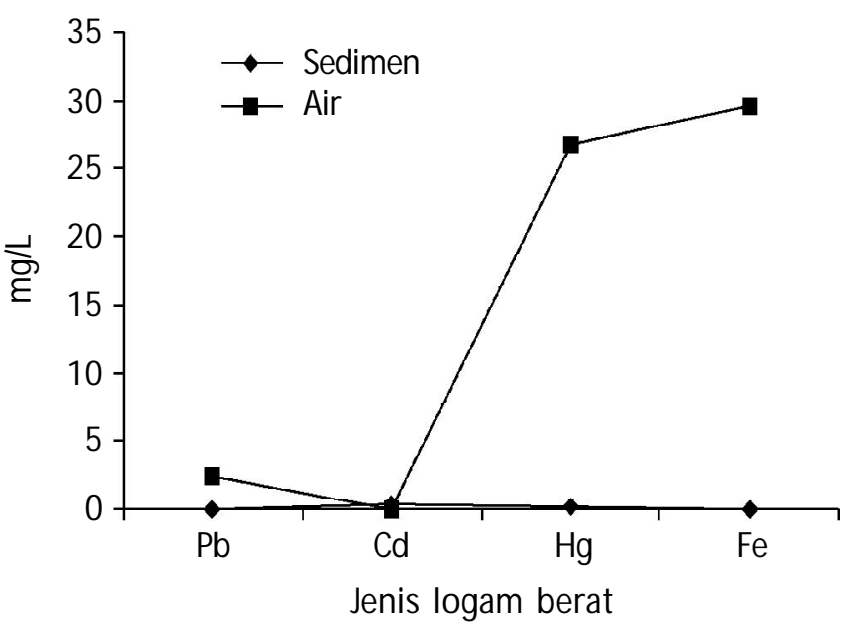

Gambar 4. Nilai akumulasi logam berat pada sedimen dan air 
Dampak negatif dari akumulasi logam berat pada sedimen terjadi pada saat terjadinya upwelling. Karena logam berat yang terakumulasi pada sedimen akan terdegradasi dan terbawa oleh arus ke permukaan air sehingga dapat mengakibatkan pencemaran pada air dan racun bagi ikan yang ada di dalamnya, bahkan tidak jarang menimbulkan kematian. Kematian letal pada ikan terjadi apabila pada waktu yang bersamaan oksigen parairan rendah, racun dari dasar perairan terbawan ke permukaan, dan konsentrasi logam berat di air menjadi tinggi. Sehingga pada kondisi perairan seperti ini kematian ikan secara massal tidak bisa dihindari lagi. Hasil analisis logam berat pada daging ikan patin disajikan pada Tabel 3.

Tabel 3. Hasil analisis logam berat pada daging ikan patin

\begin{tabular}{lccc}
\hline $\begin{array}{c}\text { Identifikasi } \\
\text { sampel }\end{array}$ & Parameter & $\begin{array}{c}\text { Hasil dari awal } \\
\text { pemeliharaan } \\
\text { (mg/kg) }\end{array}$ & $\begin{array}{c}\text { Hasil dari akhir } \\
\text { pemeliharaan } \\
\text { (mg/kg) }\end{array}$ \\
\hline \multirow{4}{*}{ Daging } & $\mathrm{Pb}$ & 0,1040 & 0,389 \\
& $\mathrm{Cd}$ & 0,0264 & 0,030 \\
& $\mathrm{Hg}$ & 0,0001 & 0,025 \\
& $\mathrm{Fe}$ & 0,5160 & 6,430 \\
\hline
\end{tabular}

Hasil analisis logam berat pada daging ikan patin Tabel 3, memberikan gambaran bahwa secara umum ikan patin yang dipelihara di KJA selama enam bulan mengalami peningkatan. Untuk logam berat $\mathrm{Pb}$ pada awal pemeliharaan akumulasinya sebesar 0,104 mg/kg, pada akhir pemeliharaan mengalami peningkatan akumulasi menjadi $0,389 \mathrm{mg} / \mathrm{kg}$ atau mengalami peningkatan sebesar $0,285(73,26 \%$. Logam berat Cd mengalami peningkatan akumulasi pada akhir pemeliharaan yaitu sebesar 0,0036 $\mathrm{mg} / \mathrm{kg}$ jika dibandingkan dengan awal pemeliharaan. Logam berat $\mathrm{Hg}$ pada awal pemeliharaan terukur sebesar $0,0001 \mathrm{mg} / \mathrm{kg}$ dan pada akhir pemeliharaan akumulasinya sebesar $0,025 \mathrm{mg} / \mathrm{kg}$, sehingga ada peningkatan akumulasi di akhir pemeliharaan sebesar 0,0249 mg/kg (1\%). Logam berat Fe yang termasuk dalan kategori logam esensial akumulasinya pada awal pemeliharaan sebesar $0,516 \mathrm{mg} /$ $\mathrm{kg}$ dan pada akhir pemeliharaan sebesara $6,43 \mathrm{mg} / \mathrm{kg}$, sehingga pada akhir pemelihaaraan mengalami peningkatan akumulasi sebesar 5,92 (91,98\%).

Peningkatan akumulasi ini, selain berakibat kurang baik para sistem pencernaan, metabolisme, reproduksi, dan tidak jarang mengakibatkan kematian. Kondisi ini akan lebih toksik lagi apabila pada saat yang bersamaan logam beratnya tinggi, oksigen di perairan rendah, dan racun yang ada di dasar perairan terbawa ke permukaan. Untuk melihat konsentrasi logam berat dominan pada sedimen dan ikan patin yang dipelihara di KJA, disajikan pada Gambar 5, 6, 7, 8 .

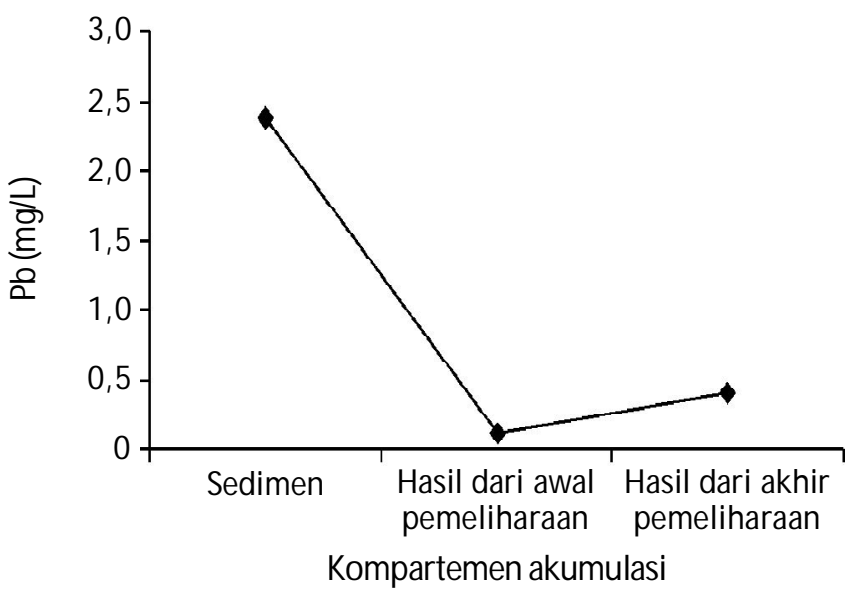

Gambar 5. Akumulasi logam berat $\mathrm{Pb}$ pada sedimen dan ikan patin

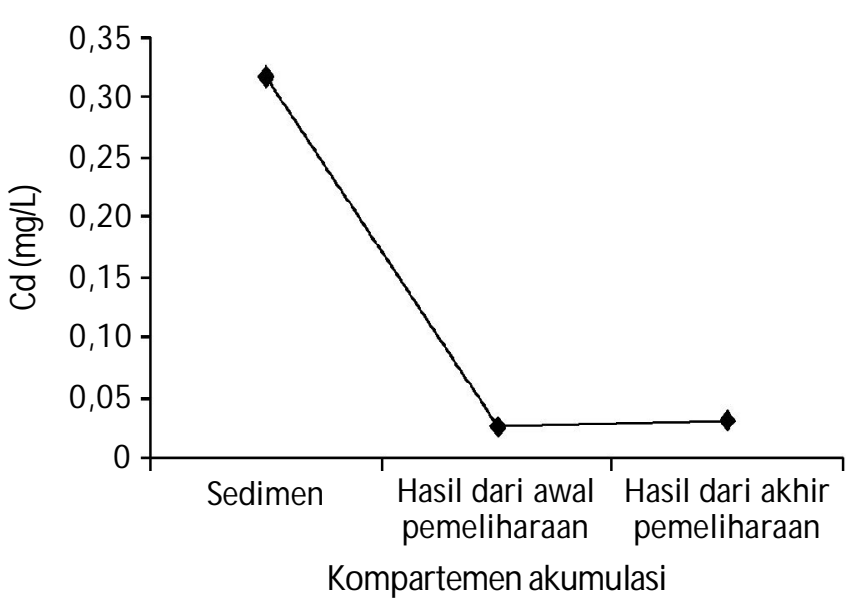

Gambar 6. Akumulasi logam berat $\mathrm{Cd}$ pada sedimen dan ikan patin

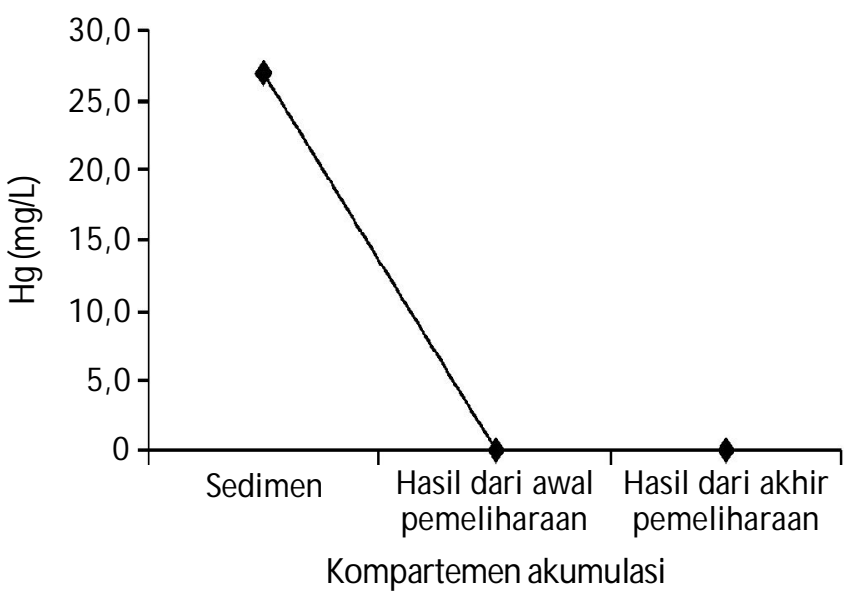

Gambar 7. Akumulasi logam berat $\mathrm{Hg}$ pada sedimen dan ikan patin 


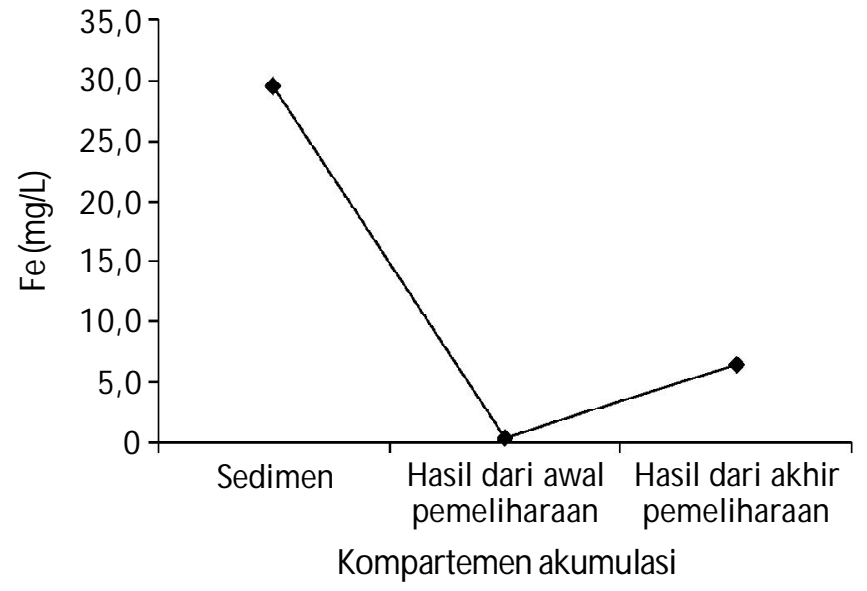

Gambar 8. Akumulasi logam berat Fe pada sedimen dan ikan patin

Pada Gambar 5, 6, 7, 8 terlihat bahwa akumulasi logam berat pada sedimen Waduk Cirata sangat tinggi. Hal ini diduga bisa memberikan dampak yang negatif dan bisa memberikan dampak terhaddap peningkatan akumulasi logam berat pada ikan yang dipelihara. Dari hasil analisis terlihat bahwa akumulasi logam berat pada ikan patin di akhir pemeliharaan konsentrasinya lebih tinggi apabila dibandingkan dengan awal pemeliharaan. Media distribusi logam berat ini bisa melalui rantai makanan yaitu plankton maupun partikel yang ada di perairan.

\section{KESIMPULAN}

Akumulasi logam berat Fe (besi) pada sedimen sebesar 29,495 mg/kg, logam berat $\mathrm{Hg}$ (merkuri) sebesar 26,83 $\mathrm{mg} / \mathrm{kg}$, kemudian disusul oleh logam berat $\mathrm{Pb}$ (timbal) sebesar 2,38 mg/kg, dan terakhir logam Cd (kadmium) sebesar $0,29 \mathrm{mg} / \mathrm{kg}$.

Tingginya konsentrasi pada sedimen, dapat meningkatkan akumulasi pada ikan yang dipelihara melalui rantai makanan dan osmoregulasi. Terlihat dari analisis terhadap daging ikan patin secara umum mengalami peningkatan akumulasi logam berat pada akhir pemeliharaan jika dibandingkan dengan awal pemeliharaan.

\section{DAFTAR ACUAN}

Anonim, 2009. Presentasi Badan Pengelola Waduk Cirata (BPWC), dalam sosialisasi Co Manajemen Perikanan Waduk Cirata untuk Stakeholder, DKP. 14-17 April 2009.
Amin, M. 2008. Kajian Kandungan Logam Berat Timbal $(\mathrm{Pb})$ dan Zeng (Ze) pada Air, Sedimen, dan M akrozoobentos di Perairan Waduk Cirata, Provinsi Jawa Barat. Tesis. Sekolah Pasca Sarjana. Institut Pertanian Bogor. Bogor, $105 \mathrm{hlm}$.

APHA, 1989. Standard Methods for Examination of Water and Wastewater $17^{\text {th }}$ edition. APHA, AWWA (American Water Work Association) and WPCF (Water Pollution Control Federation). Washington D.C. 3, $464 \mathrm{pp}$.

Connell, W.D. \& Miller, J.G. 1996. Kimia dan Ekotoksikologi Pencemaran. Y. Koestoer (penerjemah). Universitas Indonesia Press. Jakarta, $520 \mathrm{hlm}$.

Eckenfelder, W.E. 1989. Industrial Water Pollution. Plenum Press. New York, 159 pp.

Moore, J.W. 1991. Inorganic Contaminants of Surface Water. Springer-Verlag. New York, 334 pp.

Moriarty, P. 1987. Exotoxicologi. Second Edition. Academic Press. Harcout Jovanovic Publisher, London.

OAC-I Pear Verified Methods, Polices and Procedures, 1999. AOAC International thedisi 1999. 2200Wilson Blvd. Suit 400, Arlington, Virginia 22201-3301, USA.

Oktavianus \& Salmi, I.R.S. 2005. Uptake dan Depurasi Logam Timbal $(\mathrm{Pb})$ Pada Ikan Nila (Oreochromis niloticus). Jurnal Kimia Lingkungan, 1.6(2):. 75-81.

Saputra, A. 2009. Bioakumulasi Logam Berat pada Ikan Patin yang Dibudidayakan di Perairan Waduk Cirata dan Laboratorium. Tesis. Sekolah Pasca Sarjana, Institut Pertanian Bogor (tidak dipublikasikan). p. 90

Smical, A.I., Hotea, V., Orso, V., Juhasz, J., \& Pop, E. 2008. Studies on Transfer and Bioaccumulaitin of Heavy Metal from Soil Into Letuce. Journal Environmental and Management, 7(5): 609-615.

Standar Nasional Indonesia (SNI). 2004. Air dan LimbahBagian 4: Cara Uji besi (Fe) dengan Spektrofotometri Serapan Atom (SSA). Badan Standarisasi Nasional. p. 1-5.

Soemirat, J. (editor). 2003. Toksikologi Lingkungan. Gajah Mada University Press. 217 pp. 